Institute of $\mathbf{F}_{\text {ood and }} \mathbf{A}_{\text {gricultural }} \mathbf{S}_{\text {ciences }}$

\title{
Compost-formulated Media for Foliage Plant Production ${ }^{1}$
}

\section{Jianjun Chen and Dennis B. McConnell}

Composts have been widely used for vegetable, fruit, and field crop production because compost amendments improve the physical and chemical properties of the soil and suppress diseases. Another potential market for compost application is the formulation of container media for ornamental plant production. Once the plants attain marketable sizes, they and their container substrates are sold to consumers. Growers then must use new substrate materials for the next crop. With the ornamental plant industry growing at an average of $7.1 \%$ yearly, the fastest of any major segment of U.S. Agriculture, there is a constant demand for more container substrates.

Florida has been a nationwide leader in producing composted biosolids (BS), municipal solid waste (MSW), and yard trimmings (YT) and in generating various mature composts. Florida also leads the nation in ornamental plant production, particularly potted foliage plants. According to the USDA National Agricultural Statistics Service, the national wholesale value of foliage plants in 2001 was $\$ 585$ million with Florida accounting for $\$ 361$ million. Almost all foliage plants are exclusively produced in soilless media; the use of composts as components of substrates for potted foliage plant production could reduce production cost and recycle part of Florida's organic wastes. However, the marketability of foliage plants depends on their quality. Consequently, three questions must be asked when compost is considered as a component of media. Will the quality of foliage plants produced with compost-formulated media be equal to or better than that of plants produced with commercial media? What types of composts should be considered? How could composts be used to formulate potting media?

To answer these questions, we used three representative Florida composts derived from (1) two parts of MSW mixed with one part of BS based on weight (Sumter County Solid Waste Facility, FL), (2) YT (Consolidated Resource Recovery, Sarasota, FL), and (3) three parts of YT with two parts of BS based on weight (AllGro, Inc., West Palm Beach, FL) blended with sphagnum peat (SP) and pine bark (PB) in volumetric combinations to formulate 12 test media (Table 1). A common industry substrate, University of Florida container substrate 2 (UF-2, composed of 50\% SP and 50\% PB), was used as a control. We studied metal speciation of the three Florida composts, analyzed physical and chemical

1. This document is ENH873, one of a series of the Environmental Horticulture Department, Florida Cooperative Extension Service, Institute of Food and Agricultural Sciences, University of Florida. Original publication date September 11, 2002. Visit the EDIS Web Site at http://edis.ifas.ufl.edu.

2. Jianjun Chen, Assistant Professor, Mid-Florida Research and Education Center and Environmental Horticultural Department, Dennis B. McConnell, Professor, Environmental Horticultural Department at the Institute of Food and Agricultural Sciences, University of Florida. The authors appreciate AllGro, Inc., West Palm Beach, Fla., Consolidated Resources Recovery, Sarasota, Fla., and Sumter County Solid Waste Facility, Fla. for providing composted materials; Fafard, Inc., Apopka, Fla. for providing sphagnum peat and pine bark used in this research. This investigation was supported in part by the Center for Biomass Programs, IFAS, University of Florida.

The Institute of Food and Agricultural Sciences is an equal opportunity/affirmative action employer authorized to provide research, educational information and other services only to individuals and institutions that function without regard to race, color, sex, age, handicap, or national origin. For information on obtaining other extension publications, contact your county Cooperative Extension Service office. Florida Cooperative Extension Service/Institute of Food and Agricultural Sciences/University of Florida/Christine Taylor Waddill, Dean. 
properties of the 13 media, and used the media to germinate foliage and other plant seeds, root foliage plant cuttings, and grow foliage plants in shaded greenhouses from transplanting to finishing. We also evaluated the performance of plants produced in the 13 media under interior conditions (see Table 2 for plant species used in this study). After a three-year study of the representative composts, we identified and confirmed that five substrates, 1, 4, 5, 7, and 10 (see Table 1), produced high-quality foliage plants, and that plants produced in these media performed well under interior conditions. In addition to suitable physical properties, common chemical characteristics of the five substrates included low initial electrical conductivity $(\mathrm{EC})$ readings $(\leq 3.0 \mathrm{dS} / \mathrm{m})$ and low concentrations of sulfur, boron, and other mineral elements. Furthermore, these five media only shrank $15 \%$ during the production phase, which is similar to most commercial container media. These five media were formulated by combining composted MSW/BS or YT/BS volumetrically at $20 \%$ or composted YT at $50 \%$ or less with an equal amount of SP and PB.

Based on data from seed germination, rooting of cuttings, growth, interior performance of plants, and physical and chemical properties of media, we recommend the following procedures for using composts in foliage plant production:

1. Composts from different sources and natures of raw materials (feedstocks) and process methods vary in physical and chemical properties. Growers should have the following information before applying compost: feedstocks used, composting process, bulk density, color, particle size, moisture content, percent organic matter, $\mathrm{pH}$, soluble salts or $\mathrm{EC}$, carbon to nitrogen ratio ( $\mathrm{C} / \mathrm{N}$ ratio), and nitrogen, phosphorus, potassium, and magnesium concentrations. A compost that is suitable for immediate use as a component of potting media should have a $\mathrm{C} / \mathrm{N}$ ratio of 25 or less, a $\mathrm{pH}$ of 6-7.5, and an EC reading $5.0 \mathrm{dS} / \mathrm{m}$ or less. Composts derived from BS, MSW, or a mix of either BS or MSW with YT, usually possess higher concentrations of mineral elements and higher EC readings than those derived from YT only.

2. In reference to the desirable physical and chemical properties of potting media listed in Tables
3 and 4, growers can mix appropriate composts proportionally with $\mathrm{SP}, \mathrm{PB}$, or vermiculite to synthesize compost-formulated media. Our studies show that composts derived from yard trimmings can only constitute up to $50 \%$ of a potting mix if the other components are equal parts SP and PB. If composts are derived from MSW and BS or YT with BS, the compost percentage should be $20 \%$ or less with the remainder equal parts $\mathrm{PB}$ and SP. The key is to use SP and PB to dilute some undesirable factors associated with the original composts. For example, if the composts have high mineral elements and thus high EC, increased percentage of SP and PB should reduce EC.

3. After composts, SP, PB, and others are mixed, samples should be taken for physical and chemical property analyses including the parameters listed in Tables 3 and 4. Meanwhile, conduct a simple bioassay by germinating radish, pea, or wheat seeds in a compost-formulated media and a commercial substrate and calculate the percentage of germination (number of seeds germinated divided by the number of seeds sown multiplied by 100). If the percentage of germination (usually over $90 \%$ ) and plant growth or fresh weight from compost-formulated media is comparable to that of the control media and compost properties analyzed are within the desirable ranges, the compost-formulated media should be suitable for foliage plant production. 
Table 1. Components in volumetric percentage of the control substrate and municipal solid waste (MSW) with biosolids (BS), yard trimmings (YT), YT with BS, sphagnum peat (SP), and pine bark (PB) formulated compost substrates ${ }^{2}$.

\begin{tabular}{|c|c|c|c|c|c|}
\hline \multirow[t]{2}{*}{ Substrate } & \multicolumn{5}{|c|}{ Proportion of components by volume (\%) } \\
\hline & MSW/BS & YT & $\mathrm{YT} / \mathrm{BS}$ & $\mathrm{SP}$ & $\mathrm{PB}$ \\
\hline 1 & 20 & & & 40 & 40 \\
\hline 2 & 50 & & & 25 & 25 \\
\hline 3 & 80 & & & 10 & 10 \\
\hline 4 & & 20 & & 40 & 40 \\
\hline 5 & & 50 & & 25 & 25 \\
\hline 6 & & 80 & & 10 & 10 \\
\hline 7 & & & 20 & 40 & 40 \\
\hline 8 & & & 50 & 25 & 25 \\
\hline 9 & & & 80 & 10 & 10 \\
\hline 10 & 12 & 12 & 12 & 32 & 32 \\
\hline 11 & 20 & 20 & 20 & 20 & 20 \\
\hline 12 & 28 & 28 & 28 & 8 & 8 \\
\hline 13 (control) & & & & 50 & 50 \\
\hline
\end{tabular}

Table 2. Plant species used in seed germination, rooting, and production and interior evaluation when grown in compost-formulated substrates.

\begin{tabular}{|lll|}
\hline \hline Seed Germination & Rooting of Cuttings & Production and Interior Evaluation \\
\hline Arabidopsis thaliana & Saintpaulia ionantha & Cordyline terminalis \\
Brassica rapa & Codiaeum variegatum pictum & Dieffenbachia 'Camille' \\
Radermachera sinica & Dracaena marginata & Peperomia obtusifolia \\
Zea mays & Schefflera arboricola & Chamaedorea elegans \\
Eustoma grandiflorum & Maranta leuconeura & Dracaena fragrans \\
Pisum sativum & Epipremnum aureum & \\
Raphanus sativus & Hedera helix & \\
Nicotiana tabacum & & \\
Lycopersicon esculentum & & \\
Triticum aestivum & & \\
\hline \hline
\end{tabular}

Table 3. Physical properties of container substrates that are desirable for foliage plant production.

\begin{tabular}{|ll|}
\hline \hline Parameter & Desirable range \\
\hline Air space & $10-20 \%$ \\
Bulk density & $0.15-0.8 \mathrm{~g} / \mathrm{cm}^{3}$ \\
Container capacity & $20-60 \%$ \\
Moisture content & $50-75 \%$ \\
Saturated-hydraulic conductivity & $36 \mathrm{~cm} / \mathrm{hr}$ \\
Total porosity & $50-75 \%$ \\
\hline \hline
\end{tabular}


Table 4. Electrical conductivity, $\mathrm{pH}$, cation-exchange capacity, and extractable mineral elements of container substrates that are desirable for the production of foliage plants.

\begin{tabular}{|ll|}
\hline \hline Parameter & Desirable range \\
\hline $\mathrm{pH}$ & $5.5-7.0$ \\
Electrical conductivity (EC) & $1-2.5 \mathrm{dS} / \mathrm{m}$ \\
Cation-exchange capacity (CEC) & $5-50 \mathrm{meq} / 100 \mathrm{~g}$ \\
$\mathrm{C} / \mathrm{N}$ ratio & $<25$ \\
Sodium (Na) & $<80 \mathrm{mg} / \mathrm{kg}$ \\
Boron (B) & $<4 \mathrm{mg} / \mathrm{kg}$ \\
Fluorine $(\mathrm{F})$ & $<1 \mathrm{mg} / \mathrm{kg}$ \\
Sulfur $(\mathrm{S})$ & $50-100 \mathrm{mg} / \mathrm{kg}$ \\
Cadmium $(\mathrm{Cd})$ & $<2 \mathrm{mg} / \mathrm{kg}$ \\
Copper $(\mathrm{Cu})$ & $<10 \mathrm{mg} / \mathrm{kg}$ \\
Lead $(\mathrm{Pb})$ & $<5$ \\
Manganese $(\mathrm{Mn})$ & $<15$ \\
Nickel $(\mathrm{Ni})$ & $<10$ \\
Zinc $(\mathrm{Zn})$ & $<20 \mathrm{mg} / \mathrm{kg}$ \\
\hline \hline
\end{tabular}

